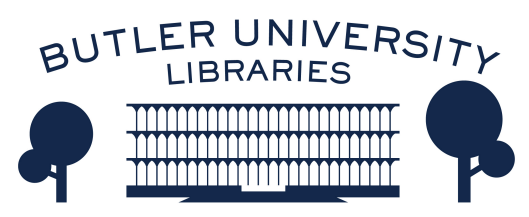

Journal of Hindu-Christian Studies

Volume 13

Article 5

January 2000

\title{
Guest Editor's Introduction: Hindu and Christian Mutual \\ Misperceptions
}

M. Thomas Thangaraj

Follow this and additional works at: https://digitalcommons.butler.edu/jhcs

Part of the Religion Commons

\section{Recommended Citation}

Thangaraj, M. Thomas (2000) "Guest Editor's Introduction: Hindu and Christian Mutual Misperceptions," Journal of Hindu-Christian Studies: Vol. 13, Article 5.

Available at: https://doi.org/10.7825/2164-6279.1225

The Journal of Hindu-Christian Studies is a publication of the Society for Hindu-Christian Studies. The digital version is made available by Digital Commons @ Butler University. For questions about the Journal or the Society, please contact cbauman@butler.edu. For more information about Digital Commons @ Butler University, please contact digitalscholarship@butler.edu. 


\title{
GUEST EDITOR'S INTRODUCTION
}

\section{Hindu and Christian Mutual Misperceptions}

\author{
M. Thomas Thangaraj \\ Chandler School of Theology, Emory University
}

THE “OTHER" REMAINS as a mystery and puzzle before one comes to know the "other" in a personal and intimate manner. Especially when the "other" is the "religious" other, it is much more puzzling and mysterious. The history of the encounter between Hindus and Christians over several centuries reveals how the "puzzle" and the "mystery" of the other can at times lead to gross misperceptions of the other. Such mutual misperceptions have been some of the stumbling blocks in the path of a healthy, friendly, and mutually enhancing relation between Christians and Hindus. In this issue of the Bulletin, we offer four essays that directly address the problem of mutual misperceptions. Before we set out to read these essays, let me offer some preliminary and introductory remarks.

In reading through the history of Hindu-Christian relations, one can detect at least three forms of misperceptions. First, there are misperceptions based on a mere lack of information about the other religious tradition. For example, Christians are quick to label Hindu worship as "idolatry", often due to a lack of knowledge about what Hindu worship means. They have neither observed Hindu puja, nor have they listened to a Hindu explain the meaning and place of image worship in the Hindu faith. Let me cite another example. During one of the workshops on interreligious dialogue held in Madurai, India, a Hindu participant told me that he knew exactly what went on in church on Sunday mornings. He said: "You, Christians, gather together to plan the strategies - almost in a military fashion - for converting Hindus to Christianity during the week!" I asked him, politely, "Sir, have you ever been to a church service on a Sunday morning?" He answered, "No". Here is a case of misperception based purely on lack of information.

Second, there are misperceptions that are caused by a generalization or universalization of a particular event or particular practice carried on by a particular group of persons within a religious tradition. For example, Swami Dayananda Saraswati of Arsha Vidya Centres writes,

A committed Christian will not wear a tilakam, much less have rangoli in front of the house. If there is no rangoli at the entrance to a Tamil Nadu house, we immediately know that it does not belong to a Hindu. A converted Christian woman ceases to wear Indian traditional clothes, like saris, etc. No Christian woman will wear a nose ring. ${ }^{1}$

I come from a family that has been Christian for five generations and I can boldly say that the description of Christians in the above quote is a highly generalized statement about Christians in Tamilnadu. Most Roman Catholic women wear tilakam, most rural Christian women wear nose rings, and Christians from the central and northern parts of Tamilnadu do decorate the entrance to their homes with rangoli. The fact that some Christians express their Christian identity by refraining from either tilakam or rangoli has been generalized in this instance.

Third, there are misperceptions that are 
generated by one's theological and political stance with regard to the other. The Southern Baptist's misperception of Hindus is motivated primarily by their theological stance on the destiny of those who do not accept Jesus the Christ as their saviour. A negative theological evaluation of Hindu religion leads invariably to a misperception and misrepresentation of it. The essays by Pennington and Sharma present a clear view of such "theologically" motivated misperceptions. For example, Pennington ably argues how missionaries like William Ward were led to misperceptions of Hinduism not on the basis of lack of information, but rather because of a prior commitment to exposing the weakness of Hinduism in order to promote the evangelistic program of the Christian community. The essays by Sharma and Neufeldt demonstrate eloquently the "political" character of such misperceptions. The idea of "Hindu Occidentalism", as explicated by Ruparell, hints at this "political" nature of our misperceptions in a very subtle and nuanced manner. While I have outlined the three misperceptions separately, one should note that mutual misperceptions occur in various combinations of these three types.

We live at a time when the issue of religious conversions has attracted the atten- tion of Hindus and Christians, much more than ever before. One of the reasons is the set of incidents of violence, both in Gujarat and Orissa, during 1999. These incidents have invited both Hindus and Christians to look carefully at the issue of religious conversions. The terms such as "conversion", "propagation", and "proselytism" need to be examined carefully by scholars who are interested in Hindu-Christian relations in the future. For such a conversation on conversion to take place, we need to create a "space" for dealing with our mutual misperceptions. The essays in this issue attempt to create such a "space". In such a space, one is encouraged to be quick to listen and slow to speak, and to be willing to give room for self-definition and self-description of one another. In such a space, one is invited to avoid caricaturing the other for one's own theological and political advantage. In such a space, one is motivated to look for the best in the "other", and in that light to probe deeply into one's own religious tradition.

\section{Notes}

1. "Conversion is an Act of Violence", Hinduism Today, November 1999, p. 52. 